\title{
The Parents' Parenting Patterns Who Work in Borobudur Temple Area with Development of Student Characters in Elementary Schools
}

\author{
Imam Mujtaba ${ }^{1}$, Ahmad Susanto $^{1}$, Dewi Lianasari ${ }^{2}$, Arif Wiyat Purnanto ${ }^{2}$, \\ Puji Rahmawati ${ }^{2 *}$ \\ ${ }^{1}$ Faculty of education, Muhammadiyah University of Jakarta, Indonesia \\ ${ }^{2}$ Department of Elementary Teacher Education, Universitas Muhammadiyah Magelang, Magelang, Indonesia \\ *Corresponding author. Email: puji.rahmawati@ummgl.ac.id
}

\begin{abstract}
This study aims to identify and analyze the parenting of parents who work in the Borobudur Temple Area on the character development of elementary school students, especially in Ringin Putih Elementary School 01 Borobudur. This type of research is a qualitative study with research subjects of parents and students of Ringin Putih Elementary School 01 Borobudur. Research data were analyzed using qualitative descriptive. The results of the data analysis show that parenting practices that work in the Borobudur temple area affect the character of students where most parents apply permissive parenting.
\end{abstract}

Keywords: parent parenting, character, student elementary

\section{INTRODUCTION}

Tourism is one of the priority sectors that has an important role in improving the Indonesian economy. Tourism in general is an industry whose survival is determined by the pros and cons of the environment that shelter it and is very sensitive to damage. Without a good environment, tourism is unlikely to develop. Tourism development must pay attention to the preservation of environmental quality, because in the tourism industry the environment actually has an attraction/selling power. Tourism development is one of the developments that need to be developed because through this sector the country's foreign exchange can increase so as to produce rapid economic growth in providing jobs.

In this modern era there is a new paradigm in the field of tourism. In the past, the tourism sector could improve the welfare of the community through employment opportunities in all walks of life. It turns out that it is now proven to be disastrous for the social, cultural, and environmental lives of the people themselves. Many social problems are encountered in the community after the development of the tourism sector. The development of tourism has an impact on changes in the value of human life. The smallest unit in the order of the value of human life is the family. In the family the role of parents is very important for children's development. Parents are the first environment for children and are very important in every child's development, especially the child's personality development. Therefore, the right way to care for children is needed so that the characteristics of the child that parents expect are formed.

The forms of parenting parents are very closely related to the personality of the child as an adult. Education in a family that is good and right will affect the personality development and characteristics of children. Parenting has an important role for the development of moral behavior of children, because the basic moral behavior obtained by children in the home comes from parents [1].

Parenting provided by parents will determine the social sensitivity and intelligence of children. Elizabeth B. Hurlock [2] said that parenting is a way for parents to educate children. While Diana Baumrind [3] revealed that parenting is a way how parents' control, guide, and accompany their children to carry out development tasks towards the process of self-maturity. The needs provided through parenting will provide opportunities for children to show that they are some of the people around them. Therefore, parenting should be done to educate the responsibilities of children [4].

The existence of the Borobudur Temple tourist area on an international scale contributes greatly to the income of the surrounding communities. As one of the cultural attractions, Borobudur Temple is visited by many tourists because of the unique culture that exists in the community. This encourages the emergence of other activities as supporting tourism activities. Tourism activity is a sector that plays an important role in the development and development of the region with its contribution to the income of a region. This is marked by the growing growth of trading activities and services in the tourist area of Borobudur Temple.

Most of the people who live around the Borobudur temple area earn a living as traders or providers of tourism services. Thus, most of the time parents are spent in the vicinity of tourist attractions. The time to meet children is only limited so that parental care for children who are still early age is not optimal, especially if both parents are working together. It is also known that there are changes in the characteristics of children through parenting parents who move around the Borobudur temple. Changes in characteristics that occur in children is a decrease in the value of the character. Children 
who are left behind by their parents' work tend to seek outside attention, both in the school environment and in the environment of friends around.

The role of the school and family environment is very important in shaping the character of children considering the level of psychological development of children in the school age range is when the child experiences puberty. At puberty (age 8-17 years) the brain undergoes a very significant structural change where the part of the brain that processes emotions such as anger develops first than the part of the brain that is able to control emotions more intensely [5]. This is what makes teenagers often rebel and try new things to find their true identity.

The role of the teacher and parent as a child's companion is needed to facilitate and direct the child to activities, activities, and positive thinking so as to form the desired character in accordance with the basic Pancasila. Responding to the problems that involve many teenagers today, it is important to introduce character education as early as possible to elementary school students. The introduction of character education since elementary school is expected to be a good mental foundation for students when facing a period of growth and development at the level of further education.

The development of theories that produce parenting models aims to describe how parents at home and their implications for schools for academic development and student behavior [6]. Forming good character in students cannot be done instantly because it requires a process to cultivate themselves through togetherness and care between one individual with another individual. Lickona [7] as one of the initiators of character education explained several goals of character development in elementary schools including to introduce students to self-development that is far from egocentrism, mutual cooperation, and mutual respect; laying the foundations of good character in students; and develop student morale.

\section{RESEARCH METHODS}

The research method used in this study is qualitative. The use of qualitative descriptive approaches is intended so that researchers can describe field conditions relating to the research problem clearly, in detail, and accurately. The selection of a qualitative approach will be easier if faced with multiple realities where this method presents the nature of the relationship between researchers and informants directly. Besides this method also has the advantage of being more sensitive and able to adjust to the many sharpening of the mutual influence on the values encountered [8].

The data collection in this study used a purposive sampling technique with selected samples were children in SD Ringin Putih 01 Borobudur whose parents worked in the tourist area of Borobudur Temple. Data collection techniques used in this study were interviews, observation, and documentation. The instruments used were observation guidelines and interview guidelines.

The selection of research instruments is based on the variables to be measured. Sugiyono [9] revealed that observations are used when research relates to human behavior, work processes, natural phenomena and if the respondent observed is not too large. While Yus [10] argues that observation is an assessment made by observing the behavior and activities of children in a time or activity. In this study the parenting variable used the interview guide instrument aimed directly at the students' parents. Whereas student character variables are obtained through filling out observation sheets of observations during teaching and learning activities in schools and supported by the results of the homeroom teacher interviews. Interviews with homeroom teachers are used to synchronize observational data. Furthermore, the instrument used is documentation. According to Sugiyono [8], documentation is a record of events that have already passed. Documentation can be in the form of writings, drawings or monumental works of a person. The documentation in this study was used as a tool for taking pictures in the form of activities carried out during the learning process in class.

\section{RESULTS AND DISCUSSION}

Based on the findings obtained in the field of permissive parenting, there are 15 informants from 24 informants who equally apply permissive parenting. In caring for their children, parents apply the rules but the rules that are applied are never carried out. For example, when every child has a desire always fulfilled by parents and when children make mistakes is considered normal because the child still does not understand because the child's age is still quite early. It was also seen that the behavior of the child from this informant seemed to be unfavorable, showing a selfish attitude and speaking with a loud and rough intonation.

Based on the results of data analysis that has been done, several field findings are found in the form of parental permissiveness to their children. This form of permissive parenting is not appropriate to instill moral behavior in children, because it is so minimal by instilling moral ethical values. Permissive parenting encourages parents to only assume that all bad children's behavior will naturally change as the child ages. This is based on the assumption that as children age, their knowledge will also increase.

Shapiro [11] revealed that permissive parents always try to accept and educate their children as best they can, but tend to be very passive when responding to problems of child disobedience. This type of parent is not so demanding of his child, but also does not set clear goals for his child. They believe that children should develop according to natural tendencies.

The findings of research on permissive parenting are illustrated from the actions and answers given at the time of the interview with the respondent's parents. Based on the results of the study note that permissive parenting dominates parenting that is applied by parents of students at SD Negeri Ringin Putih 01 Borobudur. This is what causes the character of students at school to look bad. The dominance of parental permissive parenting is inseparable from the busy schedule of each parent with his work in the tourism sector. Therefore, it is necessary to provide a detailed explanation related to good parenting for children, namely democratic parenting. 
[2] Hurlock, E.B. (2004). Perkembangan Anak (Penerjemah: Tjandrasa, M). Jakarta: Erlangga. Jakarta: Kencana Prenada Media, 2011.

[3] Baumrind, D. 1991. The influence of parenting style on adolescent competence and substance use. The Journal of Early Adolescence, 11 (1), 56-95.

[4] M. Chabib Thoha, Teknik Evaluasi Pendidikan,(Jakarta: Raja Grafindo Persada,1996), Cet.3.

[5] Santrock, J.W. (2012). Life-Span Development (Perkembangan Masa Hidup Edisi 13 Jilid 1, Penerjemah: Widyasinta,B). Jakarta: Erlangga.

[6] Penner, "Early Parenting and the Reduction of Educational Inequality in Childhood and Adolescence" The Journal of Educational Research. http://dx.doi.org/10/1080/00220671.2016.1246407

[7] Lickona, Thomas, .1992. Educating for Character, How Our Schools Can Teach. Respect and 9, no. 4, pp. 891-902, 2017.

[8] Moleong, L.J. (2011). Metodologi Penelitian Kualitatif Edisi Revisi. Bandung: PT. Remaja Rosdakarya.

[9] Sugiyono. 2011. Metode Penelitian Kuantitatif, Kualitatif dan R\&D. Bandung: Afabeta

[10] A. Yus, Model Pendidikan Anak Usia Dini. Jakarta: Kencana, 2011

[11] Shapiro, L.E. 1999. Mengajarkan Emotional Intellegence pada Anak. Jakarta: PT Citra Angkasa. 